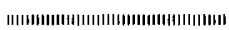

\title{
技術資料
}

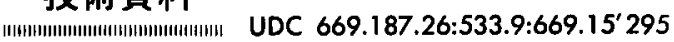

\section{積層凝固式プラズマチタン溶解炉 $(\mathrm{PPC}-\mathrm{F})$}

\author{
平竹 進*, 中西洋一*, 山田博之**, 吉田浩二**
}

\section{Plasma Progressive Casting Furnace (PPC-F) for Tita- nium Melting}

\author{
Susumu Hiratake, Youichi Nakanishi, \\ Hiroyuki Yamada and Kouji Yoshida
}

\section{Synopsis}

An industrial scale new melting process, named Plasma Progressive Casting Furnace (PPC-F) was designed and constructed by Daido Steel Co., in Daido's Hoshizaki Plant. This process is suitable for making a titanium primary ingot (VAR electrode) directly from grain sponge and/ or various shapes of scraps without requirement for compaction and electrode fabrication. The furnace has six plasma torches circling around the water cooled crucible. Plasma arcs are controlled by magnetic field which also makes molten pool rotate. Materials are fed and melted continuously and solidified ingot is withdrawn progressively.

This process has a distinctive advantage of efficient utilization of small sized scraps which is difficult to remelt in usual VAR process and a high reduction of the melting cost is accordingly expected.

\section{1. ま え がき}

チタンおよびその合金は比強度が高く，また耐 食性に優れているため航空機をはじめ,化学装置, 原子力ゃ火力の発電設備の構造材に大幅に使用さ れるようになった。

一方チタンは融点が高く，酸素や窒素などとの 親和力が強く，また耐火物とあ反応しやすいため その鋳塊製造には，真空あるいは不活性ガス雾囲 気下に怙ける水冷るつぼ内での溶解鋳造が不可欠 である。従来その工業的溶解法は, 消耗電極式真

昭和58年 8 月 30 日 受付

"大同特殊鋼的機械事業部

**大同特殊鋼侏中央研究所
空アーク溶解(VA 溶解)による多重溶解が代表で あった。棒状原料を一方の電極として真空アーク 溶解し，水冷鋳型内に積層凝固鋳塊を得るこの方 法は，原料を棒状電極に成形するためのスポンシ チタンのプレスとその溶接積み重ねといら複雑か つ大掛りな工程が必要で，しかも各種製品の加工 工程で発生するスクラップの利用がわずかしかで きないといら久点があった。

大同特殊鋼珠（以下当社という）では，昭和36 年以来高温の熱源としてブラズマフークの利用を 研究し，昭和41年には，高合金鋼を溶解するブラ ズマ誘導炉”を開発して溶解への応用を果した。 次いで,このプラズマアークをチタン溶解に用い る研究を重ね, 従来のチタン溶解の久点を解消す るプラズマ積層凝固式溶解 (PPC 溶解)を開発し， 
昨年 8 月には直径 $435 \mathrm{~mm}(2 \mathrm{t})$ のチタン鋳塊を 製造できる本格的な大型 PPC 炉を当社星崎工場 に設置した。以下に PPC 溶解の特徴と大型 PPC 炉の概要を述べる。

\section{2. プラズマアーク溶解}

\section{1 プラズマアーク}

ブラズマフークは，電極間に生じるフークをガ ス流でその周囲を覆い，熱ビンチと磁気ビンチの 作用で収樎させ温度を高めたものである。実際に は，その発生は水冷タングステン棒を陰極とし， これを絶縁された水冷銅ノズルで囲み，その裳間 に作動ガスを流してノズルの穴から噴出させるよ らにしたブラズマトーチを用いる。

溶解用トーチは，この原理をむとに給電，給気， 給排水を工夫し，炉内の諼しい環境に耐え安定で パワフルなプラズマフークを発生するよう設計さ れるもので，次の特徵をるつ。

(1) $12000^{\circ} \mathrm{C}$ の超高温を発生。

（2）指向性上く被熱物に向い，アーク長や雾囲 気圧の変化に対し安定。

(3) 不活性のアルゴンガスで作動。

（4）出力の微調整が容易。

（5）ソフトなブラズマフークが発生され，被熱 物の飛散や騒音が少ない。

（6）大電流で所望の出力を発生し熱伝達が良 い。

\subsection{PPC 溶解の特徵}

PPC 溶解は，特にチタンなどの活性金属やその 合金の溶解用に開発された技術で，水冷るつぼに 連続的に装入される原料をプラズマフークにより 浴解し，同時にるつぼの底を引下げることにより， 積層凝固した鋳塊を得るよ5にした連続溶解鋳造 ブロセスである。Fig.1にその断面図を示す。

非消耗のプラズマトーチ, 水冷金属容器, アル ゴン大気压雾囲気のニニークな組合わせにより， PPC 溶解では，次の特徵が発揮される。

（1）原料を污染なく溶解鋳造できる。

（2）原料や合金成分の蒸発による損失や変動が ない。

（3） $\mathrm{Ti}$ をはじ, $\mathrm{Zr}, \mathrm{Cr}, \mathrm{Nb}$ な゙高融点材料 の溶解が可能。

（4）多種形状の原料がそのまま利用でき，また 精鍊用スラグの添加も可能。

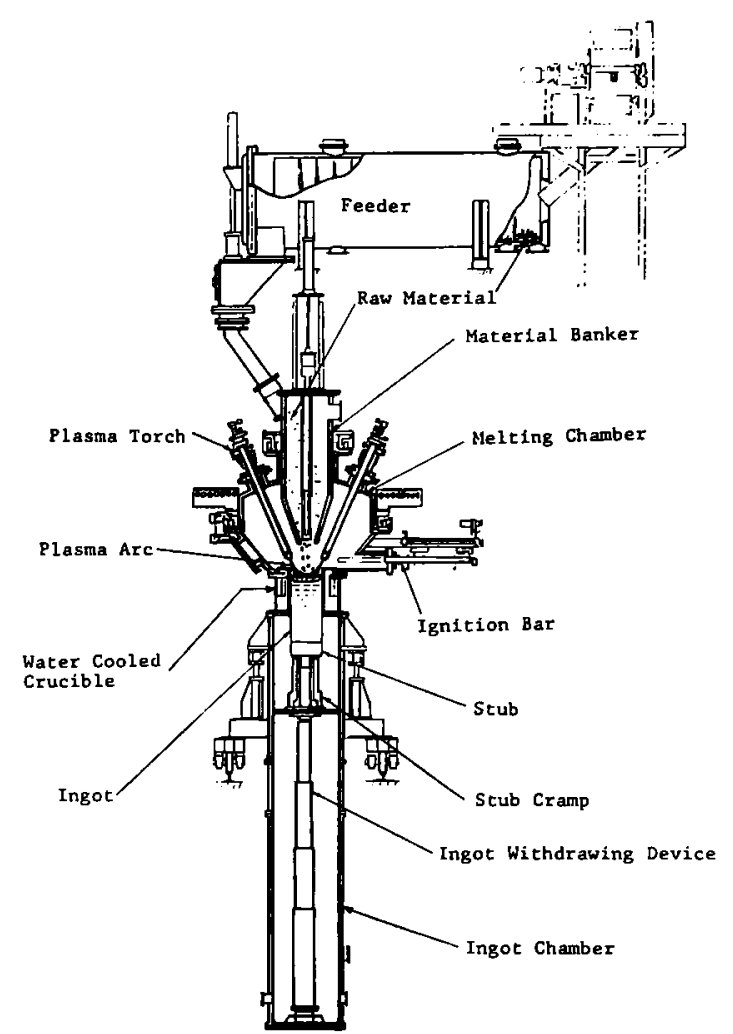

Fig. 1. Schematic cross section of industrial scale PPC-F.

（5）バワーの調整が自由で，溶解条件や凝固条 件の設定が任意に可能。

（6）均一な加熱が得られ，溶湯を线く保持でき， 良好な積層凝固が可能。

\section{PPC 炉開発経緯}

PPC 炉の研究は, 昭和 47 年の直径 $110 \mathrm{~mm}$, 重さ $25 \mathrm{~kg}$ の鋳塊を溶製する 1 本トーチの PPC 炉試作 に始まる。次いで昭和54年には直径 $200 \mathrm{~mm}$, 重さ $50 \mathrm{~kg}$ の鋳塊を溶製する 3 本トーチの炬を試作し， これらを用い純チタンや Ti- $6 \mathrm{Al}-4 \mathrm{~V}$ などの合金 鋳塊製造試験を行った。ジーシン原料（スポンジ チタン，㬄加合金など）をばめ，線材，板切れ， ダライなどの各種スクラップを原料として溶解 し, 得られた錆塊やさらにVA 再溶解した釷塊に ついて詳細な調查を行った ${ }^{2)}$ 。その結果,

(1) PPC 溶解は， $100 \%$ スクラップでも溶解可 能。

（2）不純物の増加はない。 
（3） PPC 溶解では低速溶解，高速溶解が自由 で，十分緻密なVA 用電極が得られる。

(4) PPC 溶解ではスポンジ含まれる塩化マ グネシウムが除去され，VA溶解が通常より安定 かつ容易。

（5）その二次鋳塊は，VA 2 回以上溶解材之同 等の外観, 組成, 清浄度, 偏析度, 機械的性質を 示す。

などのことが分かり，PPC一次溶解 $+\mathrm{VA}$ 再溶 解といらプロセスが，優れた品質の䤻塊をより経 済的に製造するとの結論を得た。Teble 1 に、鋳塊 品質の代表例を示す。

\section{4. 大型 PPC 炉}

Photo. 1 に, 昭和57年 8 月に設置した大型 PPC 炉の外観と溶解状況を示す。本炉は, PPC+ $\mathrm{VA}$ 溶解法に打ける一次鋳塊生産用の本格的実用 炉である。

\section{1 設計上の留意点}

設計にあたっては，前述の PPC 溶解の特徵が 最大限に生かされることはもちろん，生産性，安 全性, 操作性, 保守性の面子十分留意し次の特徵 をるたせた。

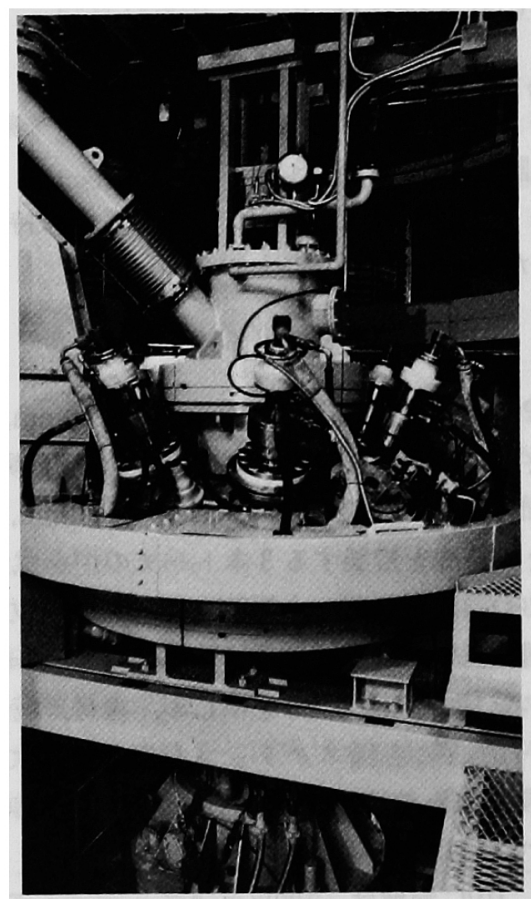

(a)
（1）原料添加、溶解，鋳造いずれも真空容器と 同じ気密構造の中で行われる。

(2) 真空排気により雾囲気を完全にフルゴンガ スに置換できる。

(3) 2 台のフィーダにより外部からバーシン材 やスクラップを連続的に円滑に供給できる。

（4）原料通路は広く，乙か子原料をるつぼ中心 にンフトに添加できる。

（5）プラズマアークはるつほ上のまわりを自動 旋回し，攪拌コイルの効果も加わり一層広範囲に 加熱する。

（6）フークの発生・停止にトーチ昇降操作は不用。

（7）るつぼは交換式で，鋳塊サイズの変更が可 能。

（8）多段シリンダ式鋳塊引下げで鋳塊室が小さ w。

(9) 炉内の異常昇圧に対し，レリーフ弁，防爆 口，るつぼ自動分離，防爆壁の 4 重の安全策をも つ。

(10) 運転操作や炉内状況の監視は，全て遠隔方 式がとられ，操作単位ごとに自動化されている。

\section{2 構成书よひ仕样}

本炉は，炉本体(原料貯留槽，容解室，るつほ，

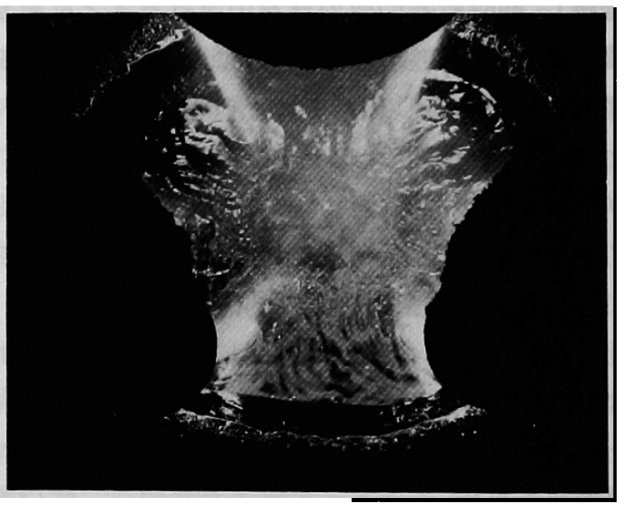

(b)

Photo. 1. Constructed PPC-2000T (a) and its sponge Ti melting states (b). 


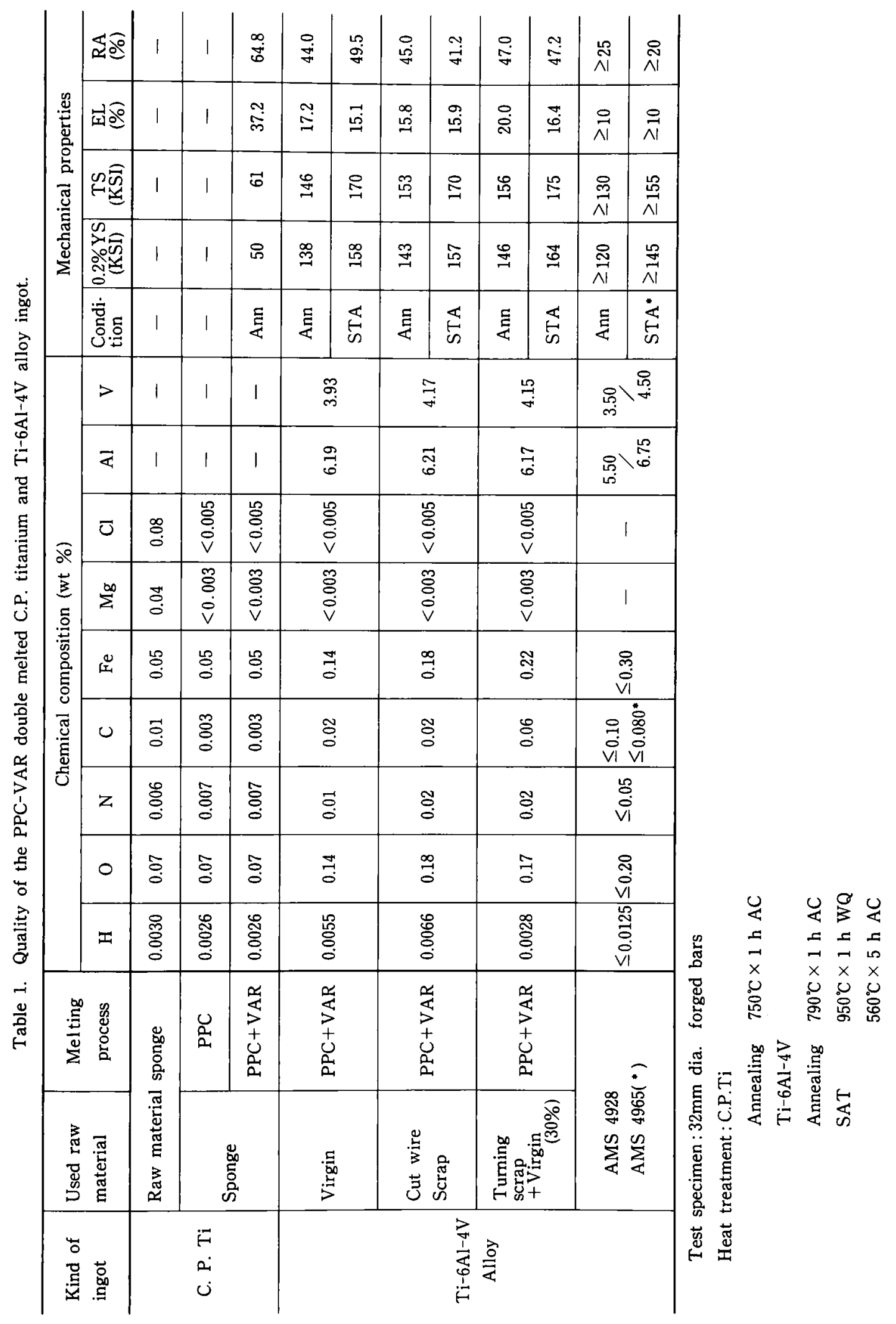



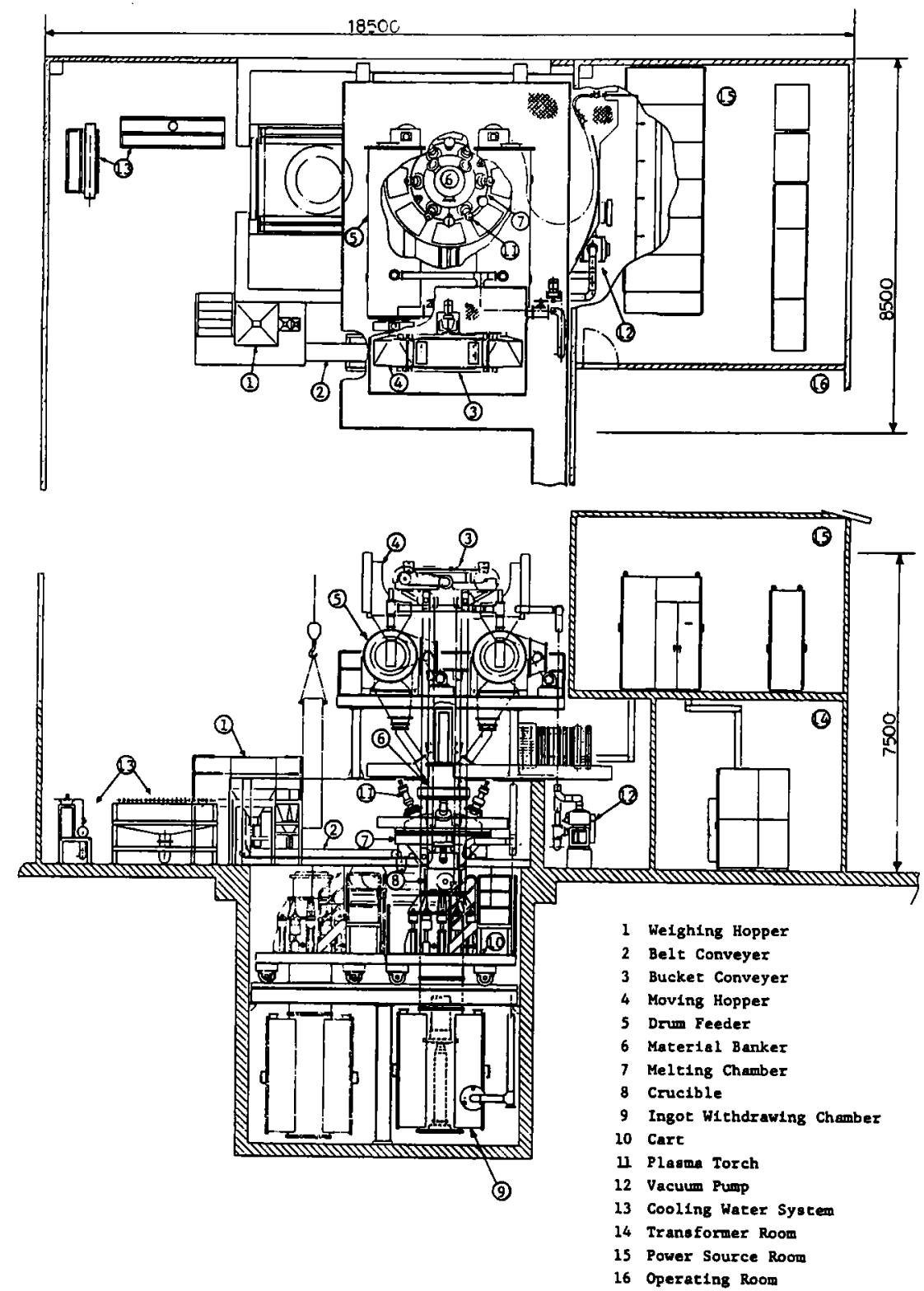

Fig. 2. Layout and side view of PPC-2 000T.

鋳塊室), 原料供給設備(科量機, ベルトよびハ ケットコンペヤ, 移動ホッハ，ドラムフィーダ, シュート), 真空排気設備(油回転ポンプ, メカ= カルプースタポンプ), 給油装置, 給気設備(アル ゴンおよび空気), 給排水設備および電気設備(プ ラズマ用直流電源装置, 動力盤, リレー盤, プラ ズマ制御盤，炉体操作盤)で構成される。Fig. 2 に その配置を示す。

また，本炉の基本的仕様は次のとおりである。
（1）用途

(2) 型式

（3）溶解原料

（4）鋳塊寸法
消耗電極用チタン鋳塊の製 造

PPC-2000T

スポンジチタン，母合金， チタンまたは合金屑（最大 $80 \mathrm{~mm}$ 角)

直径 355 および $435 \mathrm{~mm}$ 最大長さ $3000 \mathrm{~mm}$ (円柱 状) 
（5）鋳塊重量

(6) プラズマ出力

最大 $2000 \mathrm{~kg}$

（7）溶解雾围気

(8) 原料フィーダ

（9）到達真空度

$540 \mathrm{~kW}$

フルゴンガス（大気圧）

回転ドラム $(260 \mathrm{~kg} /$ 台 $\times 2$

台, 切出速度 $1 \sim 8 \mathrm{~kg} / \mathrm{min}$ )

主電源：三相，60Hz，3300V，1220kVA 冷却水： $1.2 \mathrm{~m}^{3} / \mathrm{min}$

王樎空気： $5 \mathrm{~m}_{\mathrm{N}}{ }^{3} /$ チャーシ (最大 $1.5 \mathrm{~m}_{\mathrm{N}}{ }^{3}$ / $\min$ )

フルゴンガス；溶解中 $0.3 \sim 0.7 \mathrm{~m}^{3}{ }_{\mathrm{N}} / \mathrm{min}$ ガス置換時最大 $1 \mathrm{~m}_{\mathrm{N}}{ }^{3}$ / $\min \times 8 \mathrm{~min}$

\section{3 原 料 供 給}

原料は，まず精度士0.05\%の自動科量機に入れ られる。科量機はチタンおよび2種類の合金母材 をそれぞれの貯蔵ホッパより電磁フィーダで切 出し，ロードセルにて所定の配合率になるよ5 1 回 $20 \mathrm{~kg}$ 単位で科量する。科量を終った原料は，3 銘柄が混合してペルトコンベヤ上に切出され，フ ロフ面を搬送されてバケットコンベヤに導かれ る。このコンベヤは，炉体上方に設けたドラムフ 1ーダへ原料を運ぶもので，13個のバヶットから なり，それぞれに $20 \mathrm{~kg}$ ずつ原料を受けとる。ここ までの操作を六ケッ市装之と称し，自動的に行わ れる。これが終わるとドラムフィーダの装入側扉 が開き，移動ホッバがその開口部へ移動して，ハ ケット内の原料をドラムフィーダ内に送り込む。 ドラムフィーダは, 内径 $1100 \mathrm{~mm}$, 長さ $3800 \mathrm{~mm}$ の円筒気密容器に，ほぼ内接する大ささの回転ド ラムを入れたすのである。回転ドラムの内面には 螺旋の仕切りがあり，方公装六の操作により合 計 13 仕切りに $20 \mathrm{~kg}$ ずつ原料が自動装入され る。觇云装入が終るとホッバが退避し，装入側 扉が閉じて内部が $6.5 \mathrm{~Pa}$ に真空排気され，その後 アルゴンが大気压まで适入される。溶解が始まり 原料供給時期になるとドラムフィーダの切出側シ ール升が開き，ドラムの回転により仕切り内の原 料が混合されながら出口に移動して切出しが開始 する。切出された原料はシュートを通り溶解室内 の原料貯留槽へ向5。原料はここで制動を受けて 速度をゆるめ,そのままるつぼの中央に落下する。 回転ドラムは $0 \sim 0.4 \mathrm{rpm}$ 範囲を铔細に速度調
整でき，るつぼへ至る原料通路む $140 \mathrm{~mm}$ 以上が 確保されているので，多種形状の原料が定量かつ 円滑に供給できる。ドラムフィーダは 2 台あり， 一方が切出し中に他方に原料が装入され， $260 \mathrm{~kg}$ 切出しごとに切り替えられる。この繰返しの操作 は，原料供給と称し，ガス置換を含めて自動化さ れている。また各ハィットやドラム内での原料の 装入状態は，操作室にグラフィックで表示され， 一目で残量が確認できる。

\section{4 溶 解 鋳 造}

溶解室の炉殻は内径 $1700 \mathrm{~mm}$, 高さ $1200 \mathrm{~mm}$, 内面がステンレス, 外面が軟鋼の水冷シャケット 構造で，上下に分割されている。上部の中央開口 部に原料詝留槽が插入され，その回りには6本の プラズマトーチがるつぼ内部に向けて対称に取付 けられている。下部には，ブラズマフークを発生 させるための点弧棒が，トーチ直下まで出し入れ 可能に取付けてある。下部はファフに固定されて 㾂解室全体を支え，上部はローラで支えられ原料 貯留槽のまわりに回転できるようになっており， 6 本のトーチを最大 \pm 60 度, 最高 $1 \mathrm{rpm}$ の速度で 旋回できる。この旋回には油圧シリンダが用いら れ，旋回が円滑で気密が確保されるよう接続部は 特別に工夫されている。

るつぼは, 内面が銅, 外面がステンレスのジャ ケット式水冷構造である。内部には、ソレノイド コイルをあち, 直流おょび低周波の交流磁界を発 生する。

鋳塊室は, 内径 $900 \mathrm{~mm}$, 内高 $5500 \mathrm{~mm}$ で, 内 部に鋳塊引下げ装置をもち，4本の油王ジャッキ により台車に支持されている。鋳塊室の上にはる つぼが載り，油压シャッキの上昇とそれに続くバ ネの力でるつぼが溶解室に連結される。鋳塊引下 げ装置は，多段式油圧シリンダとその上に取付け たスタブクランプよりなる。溶解に先立ち, VA 溶 解で残されるスタブをクランプし，多段シリンダ を伸ばしてるつぼの内部に置く。

溶解を始めるには, 炉内をまず真空に排気する。 $7500 \ell / \mathrm{min}$ の油回転ポンプと $1500 \mathrm{~m}^{3} / \mathrm{h}$ のカ ニカルブースタポンプが用いられ，13minで 6.5Paに排気する。その後アルゴンを導入し大気圧 に保持する。これらの操作は，炉体ずジ置換 の操作で自動的に行われる。

次に給水，受電を行って溶解体制を整え、ブラ 


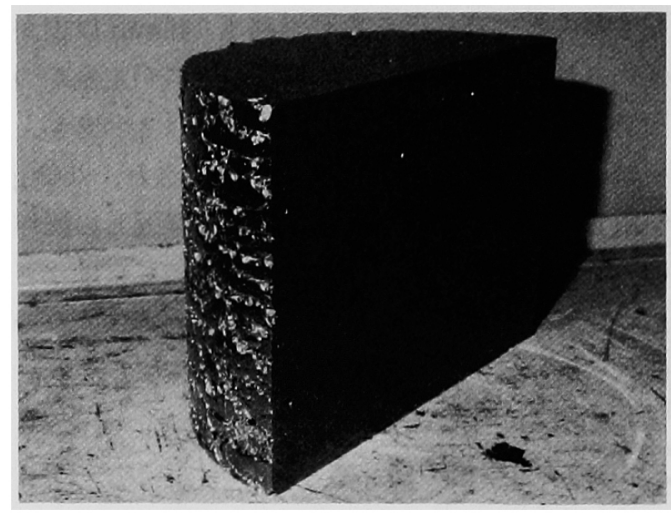

(a)

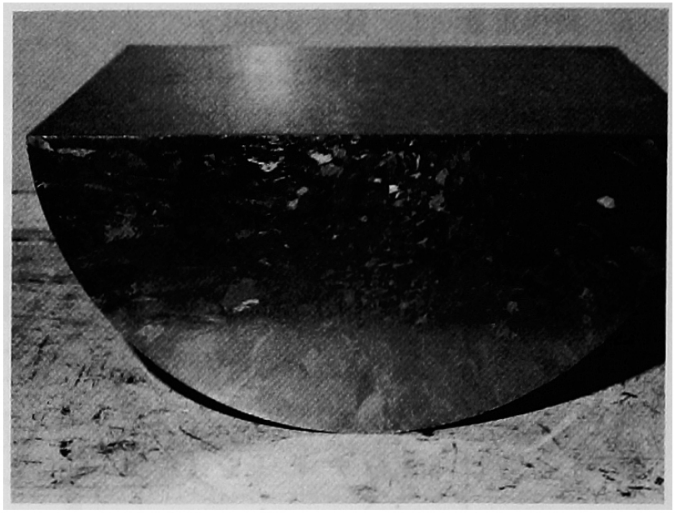

(b)

Photo. 2, Cross sections of PPC melted Ti ingot (a) and PPC + VAR melted $\mathrm{Ti}$ ingot (b).

ズマフーク点弧に移る。トーチ点弧の操作により， 自動的に点弧棒挿入, ヘイロットアーク点弧, メ インアーク発生, 点弧棒退避が行われ, プラズ、 フークがるつぼ内に向いスタブ端面の溶解が始ま る。溶解状況は，2 台のカラーITVにより操作室 で詳細に知ることができる。6本のトーチへの給 電には，高圷受電盤，力率改善コンデンサ盤，高 圧变圧器が各 1 台と 6 台の点弧回路付サイリスタ 盤からなる専用直流電源か用いられる。これは， 定電流とンフトスタートに優れ，単独 6 回路と 並列 3 回路のいずれも出力でき，複数のト一千の 電流を一つの設定器で広範团倍整できる。

スタブ端面の溶解が進み溶湯が形成されると， 前述の原料供給の操作で原料が溶湯中央に添加さ れ,引続いて鋳塊引市げの操作により多段シリン ダが低速下降を始める。その進行と共に溶湯下部 がるつ隹で冷やされ，次第に生長した積首凝固塊 が鋳塊室内に引出されてくる。この間, プラズ、 アークは，磁界発生コイルによってアークの方向 を制御されながらトーチの自動旋回によって旋回 し，るつぼ内全体を照射して添加される原料を急 速に溶解する。また溶湯も磁界による摫汼力を受 け，加熱が均一に行きわたる。

鋳塊引下げ量は，鋳塊室に設けたストローク計 の信号を受信し，操作盤に図で表示される。溶解 速度は,ドラムの回転速度の調整で決まり，これ に合せて鋳塊引下げ速度を設定するが，運転者は 一度設定した後はほとんど操作の必要がない。ま
たトーチの操作についても，湯温のコントロール のための初期のパロー調整の外は， 汪とんと操作 が不要である。このため本炉は一人の作業者で運 転できる。

チタンの消耗電極用鋳塊製造では，真比重の 90 \%の比重の鋳塊を得るような高速度でる原料を供 給できる。そのため直径 $435 \mathrm{~mm}$ の釷塊製造では $300 \mathrm{~kg} / \mathrm{h}$ 以上の速度で溶解でき, 電力原単位も $1800 \mathrm{kWh} / \mathrm{t}$ 以下が可能である。

溶解中は常時露点計で炬内雾围気が監視され， また何らかの原因で炉内が異常に昇圧した場合， レリーフ弁が開きささらに圧力が高くなるとるつぱ が自動的に容解室から分離し，溶解室に取付けた 防爆口が破壊して炉内圧を逃がす。作業者は，運 転中炉体回りの防爆壁内に入る必要がないため, 危害が及ぶことがない。

\section{5 鋳塊取出 ᄂ}

溶解か所定量終了すると, アーク停止の操作で 自動的に冷却プロセスに入り，アルゴン霝团気を 䧽持して鋳塊が冷やされ，その後空気に置換され る。冷却後は，鋳魄室昇降ジャッキを操作してる つぼと鋳塊室を台車に載せ，油圧駆動で水平に移 動して鋳塊取出し位置に移す。るつ济をクレーン で除きスタブクランプを解除して鋳塊をクレー ンで吊り出す。取出された鋳塊は，そのま上下 逆にしてスタブ部分をVA昵にクランプし，消耗 䉓極として再溶解される。Photo. 2 にPPC 溶解 した鋳塊とさらにVA 溶解した鋳塊を示す。 


\section{6 溶解サイクルタイム}

PPC 溶解における一連の作業時間を次に示す。

・鋳塊取出し扣よび溶解準備； $72 \mathrm{~min}$

・原料のバケット装入 ；12min

・原料のドラム装入 ；10 min

・溶解炉本体フルゴン置換 ； $14 \mathrm{~min}$

- 溶解鋳造 ；300 - 400min

・冷却および空気置換；

すなわち，溶解の1サイクルは11〜13hとな

り，3 直稼動では月産 75t 以上が可能である。

5. あと がき

本稿では，新設された世界的にも例のない大型 のチタン溶解用プラズマアーク炉について紹介し た。PPC 溶解はまだ実用の途に着いたばかりで， 今後ここにあげた以上の有効な利用が見出される 可能性がある。本炉はもちろんニオブやジルコニ ウムなどの他の活性金属にも適用でき，また各種 機能材料（水素吸蔵合金, 形状記憶合金, 超伝導 合金など)の容解炉としても有効であろ5。ま た，現在の構造を基に，生産性向上のための二鋳 塊室のbのや，工具片で污染されたスクラップの 除去を可能にするスカル溶解を追加したハース付 PPC 炬も将来期待されよ5。当社では，既に明ら かにした独特の効果を生む耐熱鋼の再溶解人の利 用3)含み，さらに技術の払大を図っている。既に 6tの PPC 炉の設計む完了しており，広く需要家 の御要望に沿いたいと考えている。本稿か，読者 各位の今後の溶解プロセスを検討する上で参考に なれば幸いである。

\section{（文献）}

1）野田, 浅田, 江口, 足立, 林：“プラズマア ーク溶解についで電気製鋼，41(1970）4， 13

2) T. Fujiwara, T. Kato, H. Ono, H. Yamada:"Primary melting of titanium with plasma arc" Titanium' 80 , Science and Technology

3) 藤原, 加藤, 小野, 山田：“プラズマアーク による鋼および超合金の再溶解”鉄と鋼, 63(1977))13, 2224 